\title{
Uncovered Interest Rate Parity and Analysis of Monetary Convergence of Potential EMU Accession Countries
}

\author{
Oliver Holtemöller* \\ Humboldt-Universität zu Berlin
}

September 2003

This paper analyzes deviations from uncovered interest rate parity which are interpreted as indicator of the substitutability of currencies. Backward recursive statistical tests and error correction models are applied to study the co-movement of interest rates, and rolling regressions are used to illustrate size and volatility of country specific risk premia. In accordance to their degree of monetary integration with the Euro area, EU acceding and accession countries are divided into three groups. Additionally, the results show that uncovered interest rate parity is well supported by empirical evidence if it is augmented by a country-specific risk premium.

JEL classification: C22, C32, F36, F41.

Keywords: Cointegration, economic convergence, European monetary union, monetary integration, interest rate parity.

\footnotetext{
* I thank Carsten Trenkler, Jürgen Wolters and participants of the joint econometrics seminar of HumboldtUniversität zu Berlin and Freie Universität Berlin for helpful comments. Financial support from the Deutsche Forschungsgemeinschaft (SFB 373, TP C3) is gratefully acknowledged. Author's address: Freie Universität Berlin, Institut für Statistik und Ökonometrie, Boltzmannstr. 20, D-14195, Germany, phone: +49(0)30-83856358, email: holtem@wiwi-hu-berlin.de.
} 


\section{Introduction}

In December 2002, the European Union has closed negotiations for EU membership with 10 acceding countries. These countries are Cyprus, the Czech Republic, Estonia, Hungary, Latvia, Lithuania, Malta, Poland, the Slovak Republic and Slovenia. It is planned that these countries join the EU in time for the elections to the European Parliament scheduled for June $2004{ }^{1}$ Three other countries have applied for membership: Bulgaria, Romania and Turkey. However, negotiations have not yet started with Turkey, or are not yet closed in the case of the two accession countries Bulgaria and Romania. Unlike Denmark and United Kingdom, the ten acceding countries do not have a special status with respect to the European Monetary Union (EMU). They will join EMU with the status "countries with a derogation" and are supposed to adopt the Euro as soon as economic convergence is achieved (European Central Bank, 2002a). Sweden holds also the status of a country with derogation and is committed by the Treaty establishing the European Community to adopt the Euro. Because Sweden has not joined the European Exchange Rate Mechanism (ERM II) yet, it can not fulfill one of the Maastricht criteria, namely membership in the ERM II for at least two years without devaluation, see European Central Bank (2002b, p. 3).

The purpose of this paper is to analyze convergence of interest rates and stability of exchange rates in the EU acceding and accession countries. The EU members Denmark, Sweden and United Kingdom are also included in the analysis. The results are compared with evidence for Greece which has entered the Euro area in January 2001. Cyprus and Malta are excluded form the analysis because of their minor economic importance (about $1.2 \%$ of accession and acceding countries' population and about $3 \%$ of accession and acceding countries' GDP, see European Central Bank (2002a)) and the lack of reliable data. Following uncovered interest rate parity theory, the difference of domestic and foreign interest rates should correspond to expected exchange rate change plus risk premium. When reaching economic integration, this risk premium should disappear such that the development of the risk premium can be interpreted as measure of monetary integration. This is only one aspect of economic integration; fiscal policy indicators, inflation rate and legal system, inter alia, are other important factors which are not considered here. An overview of the overall convergence processes in EU acceding and accession countries is given for example by Piazolo (2000). Additionally, this study can also be interpreted from another perspective. Given the result that deviations from uncovered interest rate parity behave in the way that has been described above, empirical evidence is provided which supports the inclusion of uncovered interest rate parity in macroeconomic models for open economies.

The econometric procedure applied in this paper and the country-specific empirical results provide useful information for the assessment of the acceding countries' convergence procedure in terms of the development of country-specific risk premia. This information is important for at least two reasons: (1) It reveals how participants in financial markets assess the convergence status of the acceding countries. Costs and benefits of EMU enlargement will depend inter alia on financial markets' confidence in the proper selection of new EMU members ${ }^{2}$, and public confidence is reflected in convergence of interest rates and exchange rate stability. (2) Structural theoretical models describing monetary convergence and integration are needed to analyze

\footnotetext{
${ }^{1}$ Detailed information about negotiations and the accession process can be found on the homepage of the EU Commission: http://europa.eu.int/comm/enlargement/intro/index_en.htm.

${ }^{2}$ See de Grauwe (2003a) for a general discussion of costs and benefits of European Monetary Union; Bayoumi and Eichengreen (1997) provide an optimal currency area (OCA) index for European countries, and de Grauwe (2003b) discusses OCA aspects of EMU enlargement.
} 
welfare effects of monetary policy strategies in general and of the European integration process in special. As uncovered interest rate parity is an important component of theoretical monetary international economic models, the empirical evidence reported in this paper may serve as stylized facts which may be useful for the specification, parameterization and also for the evaluation of theoretical models.

The main result of this study is that some countries show stationary interest rate spreads against Euro area interest rate, low or decreasing risk premia and low or decreasing volatility of risk premia while others face high or even increasing risks signalling problems with the convergence and integration process. According to the presented results, Estonia may be seen as the country with the highest degree of monetary integration; on the other hand, Hungary exhibits still a non-stationary interest rate spread (about 3.01 percentage points in May 2003), a significant risk premium of about $9 \%$ and increasing volatility.

\section{Methodological Issues}

\subsection{Uncovered Interest Rate Parity and Substitutability of Currencies}

Interest rate parity is a core component of most macroeconomic models for open economies. Taylor (1993), for example, uses interest rate parity as one equation in his multicountry model for the analysis of macroeconomic policy questions. Merlevede et al. (2003) analyze various aspects of integration of EU acceding countries with the Euro area in a model in which interest rate parity is part of the nominal exchange rate equation. The model applied by Batini and Haldane (1999) for the discussion of monetary policy rules does contain interest rate parity as one of its equations. Interest rate parity is also part of the so-called new open economy macroeconomics models based on the Redux model of Obstfeld and Rogoff (1995), for a recent exposition see Mark (2001).

Based on arbitrage considerations uncovered interest rate parity (UIP) states that the interest rate differential between two countries has to equal the expected change in the exchange rate. ${ }^{3}$ Denote the domestic nominal interest rate per annum in period $t$ by $i_{t}$, the corresponding interest rate of the reference country by $i_{t}^{*}$, and the exchange rate in terms of reference currency per domestic currency by $S_{t}$, then UIP for monthly data can be written as:

$$
\frac{12}{k} \Delta_{k} s_{t+k}^{e}=i_{t}^{*}-i_{t}
$$

where $s_{t}=\ln S_{t}, \Delta_{k} s_{t+k}^{e}=s_{t+k}^{e}-s_{t}, k$ is the maturity in months related to the interest rates, and superscript $e$ indicates expected values. Domestic and foreign interest rate have to be identical with respect to maturity, uncertainty, default probability etc. of the corresponding asset. The factor $(12 / k)$ annualizes the expected exchange rate change in order to have the same horizon as the interest rates. According to UIP, a higher domestic interest rate indicates an expected devaluation of the domestic currency while a lower domestic rate than the reference interest rate indicates an expected appreciation of the domestic currency.

However, this strict form of UIP can only be expected to hold, if foreign and domestic currency are perfect substitutes. This is rather seldom the case such that the relation has to be augmented

\footnotetext{
${ }^{3}$ For a textbook treatment of interest rate parity see for example Krugman and Obstfeld (2003) or the more advanced book by Mark (2001) and the references given there, recent discussions about UIP and capital market efficiency can be found in Levich (1989), McCallum (1994), Engel (1996), Chinn and Meredith (1998), and Cheung et al. (2002), for example.
} 
by a country-specific and possibly time varying risk premium $\phi_{t}$ :

$$
\frac{12}{k} \Delta_{k} s_{t+k}^{e}=i_{t}^{*}-\left(i_{t}-\phi_{t}\right)
$$

or

$$
\phi_{t}=\left(i_{t}-i_{t}^{*}\right)+\frac{12}{k} \Delta_{k} s_{t+k}^{e} .
$$

The risk premium is positive if the domestic interest rate is higher than UIP predicts. The time path of $\phi_{t}$ can ex post be interpreted as an indicator for the substitutability of domestic and reference currency by replacing the expected exchange rate change with the ex post observed exchange rate change. If a systematically positive or negative risk premium exists, the two currencies are not yet close substitutes, which indicates that monetary integration has not been achieved yet. On the other hand, if the risk premium fluctuates with low or diminishing variance around zero, domestic and reference currency are accepted as close substitutes which may be interpreted as evidence in favor of economic integration. Imposing on average correct exchange rate change expectations by replacing $\Delta s_{t+k}^{e}$ by $\Delta s_{t+k}$ is not very restrictive here: Large and frequent forecast errors should only occur if monetary integration is low such that the interpretation of the observed UIP deviation is not distorted by the assumption of correct exchange rate change expectations. Moreover, since expectations are assumed to be rational, expectation errors average out over time.

Deviations form UIP are also used as a measure of financial integration for a group of industrial countries by Lothian (2002). The development of country-specific risk premia in the three acceding countries Czech Republic, Hungary and Poland has been analyzed by Orlowski (2003) who distinguishes between inflation rate premium and and exchange rate premium and interprets a simultaneous decline in both premia as indicator for monetary convergence.

\subsection{Data and Empirical Methodology}

Monthly data on interest rates and exchange rates of EMU acceding and accession countries are taken from the internet home pages of central banks, some interest rates also from the International Financial Statistics (IFS) database of the IMF. ${ }^{4}$ The sample period depends on data availability. The beginnings of the samples vary between 1994:1 and 2000:1 and the sample end between 2002:12 and 2003:07. The interest rates are money market rates or time deposit rates depending mainly on data availability. The Euro area interest rate is chosen such that it corresponds to maturity and other properties of the respective interest rate selected for the individual countries. The difference order $k$ for the nominal exchange rate is chosen accordingly.

The following empirical methodology is applied. The risk premium is considered in terms of a stochastic process $\phi_{t}$. According to Wold's decomposition theorem, every covariance-stationary stochastic process can be decomposed into a deterministic process $\mu_{t}$ and a moving-average (MA) process $u_{t}$, see for example Hamilton (1994). The stochastic term $u_{t}$ can be approximated by an autoregressive moving-average process of suitable order, $\operatorname{ARMA}(p, q)$ :

$$
\phi_{t}=\mu_{t}+u_{t}=\mu_{t}+\sum_{i=0}^{\infty} \psi_{i} \varepsilon_{t-i} \approx \mu_{t}+\sum_{i=1}^{p} \rho_{i} u_{t-i}+\sum_{i=0}^{q} \theta_{i} \varepsilon_{t-i}
$$

where $\varepsilon_{t}$ is a serially uncorrelated innovation process with mean zero and constant variance. Now it can be stated that the risk premium fluctuates around a zero mean if it can be represented

\footnotetext{
${ }^{4}$ See data appendix for further details.
} 
by a stationary ARMA process without deterministic terms, that is $\mu_{t}=0$. The deterministic term should be zero because otherwise the unconditional mean of the risk premium were not equal to zero. The process should be stationary or integrated of order zero because otherwise shocks on the risk premium were persistent and the risk premium exhibited no tendency to return to its unconditional mean. Before monetary integration is achieved, a significant or even unstationary country-specific risk premium may be observed.

Given the common empirical finding that exchange rates are best described by random walks, exchange rate changes are integrated of order zero, $\mathrm{I}(0)$. This implies that the risk premium can only be integrated of order zero if the spread between the domestic and reference interest rates is stationary. Since interest rates themselves can be supposed to be integrated of order one, the interest rate spread can only be integrated of order zero if domestic and reference interest rate are cointegrated with cointegrating vector $(1,-1)$. Therefore, the first step of the econometric procedure is to test if domestic and reference interest rates are cointegrated. Backwards recursive univariate ADF and PP unit root tests as well as the Johansen trace test and likelihood ratio (LR) test for restrictions on the cointegration vector are applied for this purpose. The LR trace test for the cointegration rank would also reveal the case in which both interest rates were integrated of order zero, such that univariate unit root tests for the interest rates need not to be reported here. ${ }^{5}$ The null hypothesis of the ADF and PP unit root test is that the respective variable, that is the interest rate spread $i_{t}-i_{t}^{*}$, exhibits a unit root. The null hypothesis is rejected if the $p$-value is smaller than the desired nominal significance level. The LR trace test is a test for the rank $r$ of the matrix $\Pi$ in the vector error correction representation of a $n$-dimensional vector autoregressive (VAR) model for domestic and foreign interest rate $(n=2)$, see for example Johansen (1995) or Lütkepohl (2001):

$$
\Delta x_{t}=(\Pi: \nu)\left(\begin{array}{c}
x_{t-1} \\
1
\end{array}\right)+\sum_{i=0}^{p-1} \Gamma_{i} \Delta x_{t-i}+e_{t},
$$

where $x_{t}=\left(i_{t}, i_{t}^{*}\right)^{\prime}, \Gamma_{i}$ are $2 \times 2$ coefficient matrices, $p$ is the lag length of the level representation of the VAR model and $e_{t}$ is an 2-dimensional serially uncorrelated error term. $\nu$ reflects a constant restricted to the cointegration space. This deterministic specification implies that interest rates do not follow a linear trend and that the long-term equilibrium relation between the interest rates may include a constant term. The matrix $\Pi$ can be decomposed into two $(2 \times r)$-matrices $\alpha$ and $\beta$ such that $\Pi=\alpha \beta^{\prime}$, where $\beta$ denotes the cointegrating vector(s) and $\alpha=\left(\alpha_{1}, \alpha_{2}\right)^{\prime}$ contains the adjustment parameters. $\alpha_{1}$, that is the adjustment coefficient of the domestic interest rate, is reported in the empirical analysis. It characterizes the adjustment of the respective accession country's interest rate in direction of the long-run equilibrium between domestic and Euro area interest rate. The null hypotheses of the LR trace tests are that the cointegration rank, that is the number of linearly independent stationary relations between the variables, is at most zero $(\operatorname{LR}(0))$, and that the cointegration rank is at most one $(\operatorname{LR}(1))$, respectively. The null hypothesis is rejected if the LR trace statistic is larger than the corresponding critical value. If $r=0$ then there is no stationary relation. The existence of a stationary relationship between the interest rates $\left(\beta^{\prime} x_{t}\right)$ is indicated by a cointegration rank of $r=1$. If $r=2$ both variables are integrated of order zero. When a single stationary relation between domestic and foreign interest rate is present, it will be tested if the restriction $\beta=(1,-1)$ is rejected using the LR test for restrictions on the cointegration vector, see Johansen (1995). If this restriction is not rejected, it can be concluded that the spread $\beta^{\prime} x_{t}=i_{t}-i_{t}^{*}$ is integrated of order zero.

\footnotetext{
${ }^{5}$ An analysis of the integration properties and cointegration relations of Euro area and U.S. interest rates with different maturities is provided by Wolters (2002). He shows that Euro area interest rates with different maturities are integrated of order one which is compatible with the present case.
} 
The LR trace test for the cointegration rank is distorted for small samples in the sense that a correct null hypotheses is rejected with a probability that may differ substantially from the nominal significance level of the test. Johansen (2002b) proposes a data and model dependent correction factor which corrects the size of the test. This correction factor is taken into account in the decision on the cointegration rank. In the graphical representations of the backward recursive tests, however, only the constant asymptotic critical values are depicted. The corrected critical values vary with each recursive step and would make the graphs much less readable. ${ }^{6}$ A similar correction is possible for testing restrictions on the cointegration vector, see Johansen (2000, 2002a). Since the null hypothesis is usually rejected too often, the correction may only change the test result when the restriction is rejected. Since this is only twice the case in the empirical application (Greece and Latvia), this correction has not been implemented here.

In the second step, rolling regressions with a window of 24 observations of the type:

$$
\phi_{t}=\phi_{0}+u_{t}, \quad u_{t}=\varepsilon_{t}+\theta_{\ell} \varepsilon_{t-\ell}+\rho_{1} u_{t-1},
$$

allowing for a non-zero, locally constant risk premium $\phi_{0}$, are performed. The window size is set to 24 months because this is also the length of the reference period for the Maastricht criteria. ${ }^{7}$ The MA term is included to take into account that an MA error is possibly introduced by taking $k^{t h}$ differences of the exchange rate. The empirical calculations have shown that one $\mathrm{AR}$ and one MA term are sufficient to eliminate autocorrelation in the residuals. The inverted root of the AR polynomial is checked, and if the AR polynomial is actually stationary, it is tested within every window whether the constant $\phi_{0}$ is significant at the 5\%-level. Additionally, the standard error of the regression, $\sigma_{\varepsilon}$, is analyzed. Because there might be heteroscedasticity even in the 24 months windows, the Newey-West heteroscedasticity and autocorrelation consistent (HAC) estimator for the covariance matrix is used, see Hamilton (1994, p. 282 f.).

Together with the information about the cointegration properties of the interest rates, the recursively calculated time paths of the risk premium $\phi_{0}$ and the corresponding standard error of the residuals, which is a measure of the volatility of the risk premium, are used to assess the integration status of the acceding countries.

\section{Empirical Results}

\subsection{The Benchmark Case: Greece}

Greece has joined EMU in January 2001 and is the only country that entered the Euro area after the beginning of stage three of EMU in 1999 so far. Economic convergence of Greece has been analyzed in European Central Bank (2000, 2001). The 12-month deposit rate reported in IFS (17460L) is taken as Greek interest rate. This interest rate should reflect expectations about future monetary policy stance (the key interest rate of the Bank of Greece during the convergence process has been its 14-day deposit facility rate) and exchange rate changes. Accordingly, the 12-month Euro area deposit rate is the reference interest rate. Exchange rate changes are $s_{t+12}-s_{t}$. The results of the previously described econometric procedure for Greece are as follows. Unit root tests for the spread and the likelihood ratio test for the cointegration rank of Greek and Euro area interest rates indicate that the spread can be assumed to be integrated of

\footnotetext{
6 The corrected critical values can be obtained from the author upon request.

7 The economic development of EMU accession countries which are already members of the EU is discussed in terms of the Maastricht criteria in the Convergence Report that is published every two years in May by the ECB.
} 
order zero since the end of 1999, see figure 1. Since 1999:12, indicated by the (left) vertical line, the LR trace statistic is not only larger than the asymptotic critical value depicted in figure 1 but also higher than the corrected critical value, see table 1. At that time, the Greek interest rate has been about 6 percentage points above the Euro area interest rate and the spread stayed positive until end of 2000. However, according to the test results, the cointegration vector $(1,-1)$ has been an attractor for the Greek interest rate since then. In the corresponding VECM with one lagged difference as indicated by the Akaike Information Criterion and a constant restricted to the cointegration space, the LR test statistic for the $(1,-1)$-restriction has a $p$-value of $3.5 \%^{8}$, and the Greek deposit rate adjusts significantly (adjustment parameter $\alpha_{1}$ : $-0.07, t$-statistic: -2.82) while the Euro area deposit rate adjustment coefficient is not significant. Therefore, it is assumed in the following that the spread is stationary since 1999:12. This is also compatible with the results of the recursive ADF and PP unit root tests, see figure 1 (b). In part (c) of figure 1 , the rolling intercept $\phi_{0}$ and the rolling standard deviation of $\varepsilon_{t}$ are depicted. It can be seen that the development of deviations from UIP corresponds quite well to the results of the cointegration analysis. The average risk premium tends to zero in the beginning of the year 2000 and it stays small and insignificant when only observations from 1999:12 onwards are included in the regression (2001:11, right vertical line). There are some periods for which no average risk premium is reported. The AR polynomial in the corresponding regressions is non-stationary. It can also be seen that the standard error of the innovation process $\varepsilon_{t}$ is decreasing sharply after 1999:12 and converges at about 0.2 percentage points when only observations after 1999:12 are included in the regression, that is from 2001:11 onwards. Overall, it can be stated that Greece has been very close to integration in the beginning of 2000 confirming the decision by the ECOFIN council of June 2000 that Greece had fulfilled the necessary conditions to join the Euro. ${ }^{9}$ The uncertainty in terms of the variability of deviations from UIP have been reduced to the current level until the entrance of Greece in January 2001.

\subsection{EU Members Denmark, Sweden and United Kingdom}

Denmark and the United Kingdom have a special status with respect to EMU. They are not obliged to adopt the single currency. However, they have the possibility to join the Euro area if they declare that they are willing to join and if they fulfill the necessary conditions, see European Central Bank (2002b). Sweden does not take part in the Exchange Rate Mechanism II (ERM II) but is committed by the EU Treaty to adopt the Euro as soon as convergence has been achieved. The results for these three countries are reported in table 1 and in figures 2 to 4 . For none of these countries the evidence is unambiguous. The uncertainty seems still to be relatively high in case of Sweden and United Kingdom and their interest rates are not cointegrated with the corresponding Euro area interest rates. The trace statistic LR(0) exceeds the 5\% asymptotic critical value in case of UK but not the corrected critical value. The same result for the trace statistic can be observed for Denmark. However, the current interest rate spread (0.05) and the risk premium (0.17) are quite small, and the standard error $(0.23)$ of the rolling risk premium regression has declined strongly in case of Denmark. These results are compatible with the monetary policy strategies of these three EU members. While Sweden and United Kingdom are

${ }^{8}$ Recall that the LR test for restrictions on the cointegrating relations rejects a correct null hypotheses too often compared to the nominal significance level in small samples. Therefore, a $p$-value of $3.5 \%$ is regarded not small enough for rejection with respect to the nominal significance level of 5\% applied throughout the paper.

${ }^{9}$ Figure 1 (a) shows that the exchange rate criterion, that is a stable and non-depreciating currency in the two years prior to Euro area entrance has only been achieved by a sharp devaluation at the time of joining the Exchange Rate Mechanism in March 1998. 
Table 1: Summary of Empirical Results

\begin{tabular}{|l|c|c|r|c|c|c|c|c|}
\hline Country & Sample & Spread I $(0)$ & Spread & LR(0)/CV & LR $p$ & $\alpha_{1}$ & $\phi_{0}$ & $\sigma_{\varepsilon}$ \\
\hline \hline Greece & $96: 01-02: 12$ & $99: 12$ & 0.84 & $24.48 / 20.87$ & 0.035 & $\mathbf{- 0 . 0 7}$ & $\mathbf{1 . 7 8}$ & 0.35 \\
\hline Sweden & $94: 01-03: 05$ & & 0.77 & & & & 1.45 & 6.10 \\
Denmark & $94: 01-03: 07$ & & 0.05 & & & & 0.17 & 0.23 \\
U.K. & $94: 01-03: 07$ & & 1.29 & & & & -4.07 & 7.31 \\
\hline Czech Rep. & $94: 01-03: 06$ & $99: 07$ & 0.18 & $21.48 / 20.97$ & 0.090 & $\mathbf{- 0 . 0 5}$ & 5.50 & 5.96 \\
Estonia & $96: 01-03: 06$ & $99: 01$ & 0.62 & $93.22 / 63.53$ & 0.297 & $\mathbf{- 0 . 1 6}$ & $\mathbf{0 . 6 4}$ & 0.09 \\
Hungary & $96: 01-03: 07$ & & 7.77 & & & & 1.63 & 8.97 \\
Latvia & $94: 01-03: 07$ & $00: 07$ & 1.69 & $24.61 / 23.65$ & 0.003 & $\mathbf{- 0 . 2 1}$ & -8.17 & 6.17 \\
Lithuania & $94: 01-03: 07$ & $99: 12$ & 0.45 & $56.71 / 31.53$ & 0.243 & $\mathbf{- 0 . 1 9}$ & 2.75 & 5.53 \\
Poland & $94: 01-03: 06$ & & 1.68 & & & & -6.16 & 2.77 \\
Slovakia & $94: 01-03: 07$ & $99: 07$ & 4.26 & $34.13 / 28.97$ & 0.906 & $\mathbf{- 0 . 1 4}$ & 1.84 & 5.48 \\
Slovenia & $94: 01-03: 06$ & & 4.55 & & & & $\mathbf{2 . 1 9}$ & 0.87 \\
\hline Bulgaria & $99: 01-03: 07$ & & 0.72 & & & & 0.65 & 0.93 \\
Romania & $96: 01-03: 07$ & & 16.91 & & & & $\mathbf{7 . 1 7}$ & 10.01 \\
\hline
\end{tabular}

Notes: Column 3 (Spread I(0)) indicates since when the spread can be supposed to be stationary, column 4 (Spread) is the difference between domestic and euro area interest rate at the end of sample (December 2000 in case of Greece). Column $5(\mathrm{LR}(0) / \mathrm{CV})$ reports the trace statistic for the hypothesis $r=0$ together with corrected $5 \%$ critical values (sample beginning according to column 3), and column 6 (LR $p$ ) is the $p$-value of the likelihood ratio statistic for the test of the restriction $(1,-1)$ on the cointegration vector in the two-dimensional vector error correction model for domestic and euro area interest rate with a constant restricted to the cointegration space and lag length selection according to AIC (sample starting with period indicated in column 3). Column $7\left(\alpha_{1}\right)$ is the adjustment coefficient of the domestic interest rate in the corresponding VECM. Column $8\left(\phi_{0}\right)$ is the estimate of $\phi_{0}$ for the most recent window (1999:1-2000:12 for Greece). Bold face in columns 7 and 8 indicates significance at the $5 \%$ level. Column $9\left(\sigma_{\varepsilon}\right)$ is the standard error of regression for the most recent window.

independent inflation targeters, the goal of monetary policy in Denmark is to support Denmarks fixed-exchange rate policy toward the euro.

\subsection{The EU Acceding Countries}

The results for the EU acceding countries are presented in table 1 and figures 5 to 12 . With respect to the degree of monetary integration these countries can be divided into three groups. The first group exhibits stationary and relatively small interest rate spreads, adjustment of domestic interest rates in direction of the corresponding Euro area interest rate, small or non-significant risk premia and low or declining uncertainty. This group consists of Estonia and Lithuania. The interest rate spreads of these two countries against the Euro area are about half a percentage point and the Estonian and Lithuanian interest rates adjust significantly in direction of the euro area interest rate. The risk premium is very small in case of Estonia and not significant for Lithuania. Estonia seems to be the acceding country with the highest degree of monetary integration. The spread between 3-month Talibor and Euribor is stationary since 1999:1 which 
fits very well with the fact that the Estonian kroon has been fixed against the Euro since January 1999 (currency board); the Estonian interbank offering rate (Talibor) adjusts significantly (adjustment coefficient $-0.16, t$-statistic: -11.40$)$ in direction of the cointegration vector $(1,-1)$; the average risk premium in the most recent window (2001:7-2003:6) is about 0.6 percentage points; and the variability of the risk premium is substantially lower than in case of Sweden or United Kingdom and comparable to those of Greece immediately before EMU entrance or Denmark.

The second group does also exhibit stationary interest rate spreads against the euro area. The Czech Republic, Latvia and Slovakia belong to this group. These countries are not in the first group because of a relatively high risk premium $(\mathrm{CZ})$, a relatively large devaluation in recent time (LV) which can be seen in the negative risk premium, or a still relatively large interest rate spread (SK). Overall, however, these three countries seem to be on a straight way to monetary integration with the Euro area.

The countries in the third group are Hungary, Poland and Slovenia. The interest rate spreads are instationary for these countries. The LR trace statistic exceeds the asymptotic 5\% critical value for some samples but does never exceed the corresponding corrected critical value. This empirical result is also compatible with current economic developments in these three countries. In Hungary, the debate between central bank and government about exchange rate intervention, the inflation target and the effect of fiscal policy on inflation leads to increasing uncertainty about the future development. This is reflected in the increasing standard error of the rolling risk premium regression. The Polish zloty is depreciating since more than a year. This depreciation is stronger then the interest rate differential leading to a negative (non-significant) risk premium. For Slovenia, the interest rate spread is still relatively high, and the Slovenian tolar is depreciating continuously such that monetary integration cannot be stated yet. However, the Slovenian exchange rate policy seems to be viewed as sustainable and predictable by the financial markets which is reflected by a relatively low and stable risk premium.

\subsection{Accession Countries: Bulgaria and Romania}

According to the empirical results presented in table 1 and figures 13 and 14, Bulgaria and Romania can be put in the third group of countries. Bulgaria has introduced a currency board against the Deutsche Mark in 1997 (since 1999 against the Euro) and has been able to maintain the currency board up to now. However, the Bulgarian and the euro area money market interest rates are not cointegrated, see unit root tests and LR trace statistic in figure 13, and the uncertainty measured by the standard error of the risk premium regression is low but increasing. The example of Bulgaria shows that the introduction of a currency board is not sufficient to stabilize the relationship between domestic and euro area interest rates. Therefore, the inclusion of Estonia and Lithuania, which have both currency boards, in the first group does not simply reflect the choice of the exchange rate regime. The currency board seems to be helpful as it signals a strong commitment to stability, but it is not sufficient to achieve monetary integration like it is defined here. In case of Romania, the results are unambiguous. The Romanian 3-month money market interest rate (Bubor) is not cointegrated with the 3-month Euribor, the current spread is about 17 percentage points and there is a significant risk premium of about 7 percentage points. The decreasing speed of Romanian leu devaluation, the time paths of risk premium and standard error show that Romania exhibit a low level of monetary integration currently but is taking big steps in direction of stabilization and monetary integration. 


\subsection{Discussion of Results}

Figure 15 shows another measure of convergence of EU accession countries: the Deka Converging Europe Indicator (DCEI) calculated by the Dekabank and published in the Frankfurter Allgemeine Zeitung. This indicator lies within a range from zero to 100 and is an average of four sub-indicators based on a macroeconomic scoring model which is explained in DekaBank (2003). Sub-indicators are calculated for real convergence, institutional design, fiscal stability and monetary integration. The monetary sub-indicator, which includes inflation, long-term interest rate, exchange rate and credit growth, leads to more or less the same results than the UIP based risk premium measure. The DCEI does also indicate a high level of monetary integration of the baltic states, the Czech Republik and the Slovak Republic. The most apparent difference between the UIP based measure and the DCEI is Poland. While Poland belongs to the less integrated group according to the UIP based categorization it has a relatively high Deka scoring value for monetary integration. Recalling the fact that the absence of currency depreciation in the last two years is one of the Maastricht criteria for EMU accession, it seems plausible to follow the UIP based measure because the Polish zloty is depreciating substantially. Overall, there is broad evidence that uncovered interest rate parity - augmented by a reasonably specified country-specific risk premium - does reflect major economic developments. The empirical evidence is strictly supportive for the inclusion of uncovered interest rate parity in empirical or theoretical macroeconomic models for open economies.

A very important further conclusion can be drawn from the Deka indicator and the UIP based approach: the convergence process is not a one way street. Some countries have fallen behind their previously already achieved degree of integration, see for example the monetary DCEI and the rolling standard error for the Czech Republic. This problematic development is not only restricted to monetary integration but is also revealed by the total Deka Converging Europe Indicator, Hungary ist the most prominent example. This underlines the importance of ongoing monitoring of the integration process and should be a warning not do underestimate the necessary efforts in order to achieve monetary integration with the Euro area.

\section{Conclusions}

This paper analyzes monetary integration with the Euro area of potential EMU accession countries. The analysis is based on a measure for the substitutability of national currencies and the Euro based on uncovered interest rate parity. Greece as the last country that joined the Euro area serves as a reference case. It turns out that Estonia and Lithuania exhibit quite stable relationships between domestic interest rate, corresponding Euro interest rate and exchange rate. Another group consisting of Czech Republic, Latvia and Slovak Republic delivers results that indicate ongoing convergence and monetary integration in the near future. A third group (Hungary, Poland and Slovenia) is still faced with high and variable interest rate spreads and deviations from UIP.

Further main results of the analysis are: (i) Compared to the convergence and integration process in Greece, all acceding countries - with exception of Estonia - exhibit more instability and uncertainty than Greece two years before its entry in EMU. Therefore, still more effort of accession countries is necessary before the central and eastern Europe transition countries may benefit from monetary union. (ii) Economic and monetary convergence do not follow a one way street. Some countries, Czech Republic and Hungary for example, are currently falling behind their previously achieved degrees of convergence and integration. (iii) The uncovered interest rate parity relation - augmented by a country-specific risk premium - gives a description 
of economic development which is completely compatible with narrative evidence and scoring based indicators. This result supports the inclusion of UIP in open economy macro-models and highlights the importance of country-specific risk premia for an appropriate model specification.

Though the presented evidence is only a preliminary look on the monetary integration process and does neglect other important fields of convergence, these results are important for the assessment of the convergence process before a future enlargement of the Euro area. The empirical procedure described in this paper can be applied subsequently when new data becomes available and when accession countries start joining ERM II. It may then reveal useful information for the European integration process in the future. 


\section{Appendix A. Data}

I thank the DIW Berlin, especially Ulrich Fritsche and Vladmir Kouzine, for their support in data collection.

Table 2: Data: Description and Sources

\begin{tabular}{|c|c|c|c|}
\hline Country / Code & $i$ & $i^{*}$ & $s$ \\
\hline $\begin{array}{l}\text { Greece } \\
\text { GR }\end{array}$ & $\begin{array}{l}\text { 12-month deposit rate } \\
\text { IFS } 17460 \mathrm{~L}\end{array}$ & $\begin{array}{l}\text { deposits up to } 1 \text { year } \\
\text { ECB MB Table } 3.4\end{array}$ & IFS 174..EB.ZF \\
\hline $\begin{array}{l}\text { Sweden } \\
\text { SE }\end{array}$ & $\begin{array}{c}\text { 3-month Treasury Bill rate } \\
\text { IFS } 14460 \mathrm{C}, \mathrm{CB}\end{array}$ & $\begin{array}{c}\text { 3-month Euribor } \\
\text { ECB MB Table } 3.1\end{array}$ & IFS 144..EB.ZF, CB \\
\hline $\begin{array}{l}\text { Denmark } \\
\text { DK }\end{array}$ & $\begin{array}{c}\text { 3-month Cibor } \\
\text { CB }\end{array}$ & $\begin{array}{l}\text { 3-month Euribor } \\
\text { ECB MB Table } 3.1\end{array}$ & IFS 128..EB.ZF, CB \\
\hline $\begin{array}{l}\text { United Kingdom } \\
\text { GB }\end{array}$ & $\begin{array}{l}\text { 3-month Libor } \\
\text { CB }\end{array}$ & $\begin{array}{l}\text { 3-month Euribor } \\
\text { ECB MB Table } 3.1\end{array}$ & IFS 112..ED.ZF, CB \\
\hline $\begin{array}{l}\text { Czech Republic } \\
\text { CZ }\end{array}$ & $\begin{array}{l}\text { 3-month Pribor } \\
\text { CB }\end{array}$ & $\begin{array}{c}\text { 3-month Euribor } \\
\text { ECB MB Table } 3.1\end{array}$ & $\mathrm{CB}$ \\
\hline $\begin{array}{l}\text { Estonia } \\
\text { EE }\end{array}$ & $\begin{array}{c}\text { 3-month Talibor } \\
\text { CB }\end{array}$ & $\begin{array}{c}\text { 3-month Euribor } \\
\text { ECB MB Table } 3.1\end{array}$ & $\mathrm{CB}$ \\
\hline $\begin{array}{l}\text { Hungary } \\
\mathrm{HU}\end{array}$ & $\begin{array}{l}\text { 3-month interbank rate } \\
\text { CB }\end{array}$ & $\begin{array}{c}\text { 3-month Euribor } \\
\text { ECB MB Table } 3.1\end{array}$ & $\mathrm{CB}$ \\
\hline $\begin{array}{l}\text { Latvia } \\
\mathrm{LV}\end{array}$ & $\begin{array}{c}\text { 3-month Rigibor } \\
\text { CB }\end{array}$ & $\begin{array}{c}\text { 3-month Euribor } \\
\text { ECB MB Table } 3.1\end{array}$ & $\mathrm{CB}$ \\
\hline $\begin{array}{l}\text { Lithuania } \\
\text { LT }\end{array}$ & $\begin{array}{l}\text { 3-month Vilibor } \\
\text { CB }\end{array}$ & $\begin{array}{c}\text { 3-month Euribor } \\
\text { ECB MB Table } 3.1\end{array}$ & $\mathrm{CB}$ \\
\hline $\begin{array}{l}\text { Poland } \\
\text { PL }\end{array}$ & $\begin{array}{l}\text { 12-month deposit rate } \\
\text { CB }\end{array}$ & $\begin{array}{l}\text { deposits up to } 1 \text { year } \\
\text { ECB MB Table } 3.4\end{array}$ & $\mathrm{CB}$ \\
\hline $\begin{array}{l}\text { Slovak Republic } \\
\text { SK }\end{array}$ & $\begin{array}{c}\text { 3-month Bribor } \\
\text { CB }\end{array}$ & \begin{tabular}{|c|} 
3-month Euribor \\
ECB MB Table 3.1
\end{tabular} & $\mathrm{CB}$ \\
\hline $\begin{array}{l}\text { Slovenia } \\
\text { SI }\end{array}$ & $\begin{array}{l}\text { deposits up to } 1 \text { year } \\
\text { CB }\end{array}$ & $\begin{array}{c}\text { deposits up to } 1 \text { year } \\
\text { ECB MB Table } 3.4\end{array}$ & $\mathrm{CB}$ \\
\hline $\begin{array}{l}\text { Bulgaria } \\
\text { BG }\end{array}$ & $\begin{array}{l}\text { 1-month interbank rate } \\
\text { CB }\end{array}$ & $\begin{array}{c}\text { 1-month Euribor } \\
\text { ECB MB Table } 3.1\end{array}$ & $\mathrm{CB}$ \\
\hline $\begin{array}{l}\text { Romania } \\
\text { RO }\end{array}$ & $\begin{array}{c}\text { 3-month Bubor } \\
\text { CB }\end{array}$ & $\begin{array}{c}\text { 3-month Euribor } \\
\text { ECB MB Table } 3.4\end{array}$ & $\mathrm{CB}$ \\
\hline
\end{tabular}

Notes: IFS denotes International Financial Statistics of the International Monetary Fund, ECB MB the monthly bulletin of the European Central Bank. CB refers to the respective national bank's internet homepage. Country codes according to ISO (www.iso.ch/iso/en/prod-services/iso3166ma/02iso-3166-code-lists/list-en1.html). 


\section{Appendix B. Figures}

Figure 1: Results for Greece

(a) Data
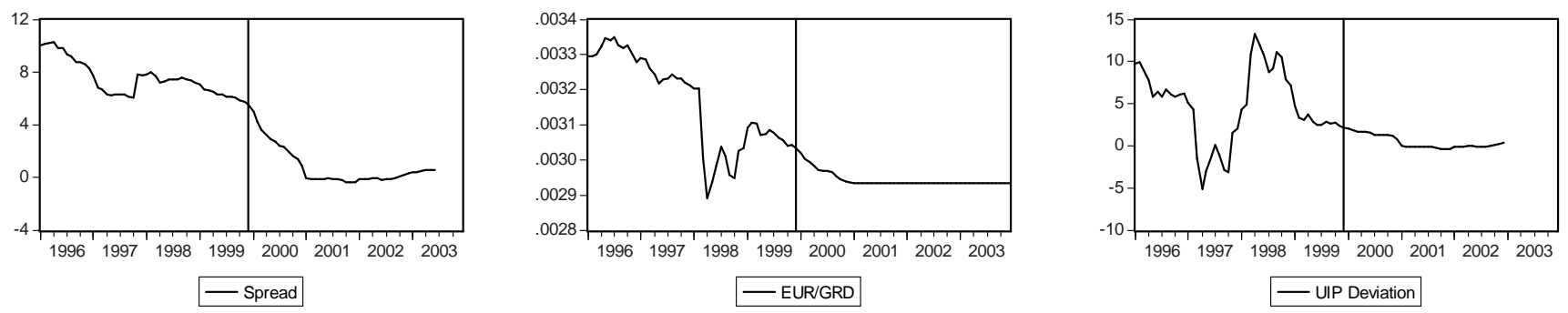

(b) Unit Root Test $p$-Values for the Spread and LR Trace Statistics for the Cointegration Rank
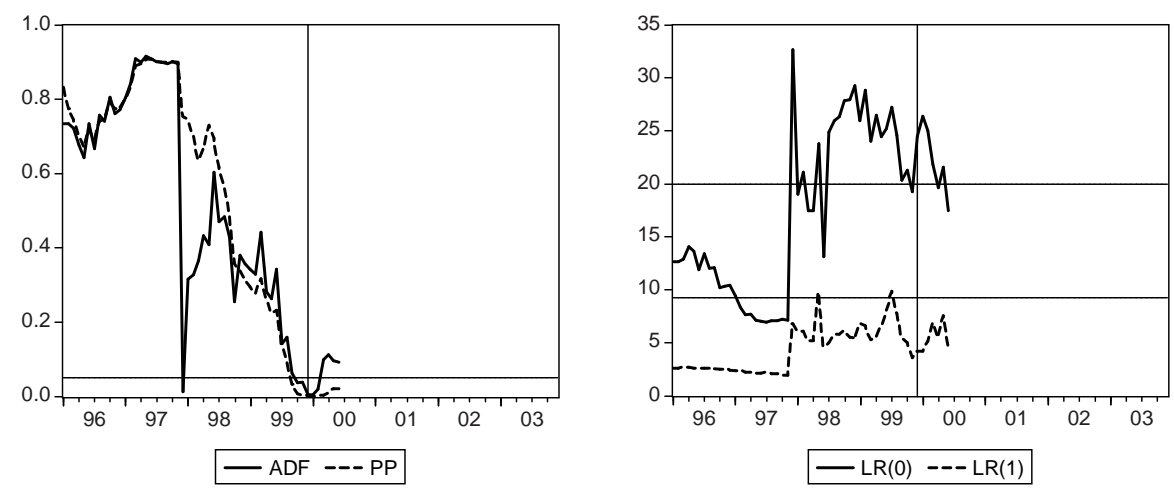

(c) Rolling Risk Premium with 2-Standard-Error Bands and Standard Error of Regression
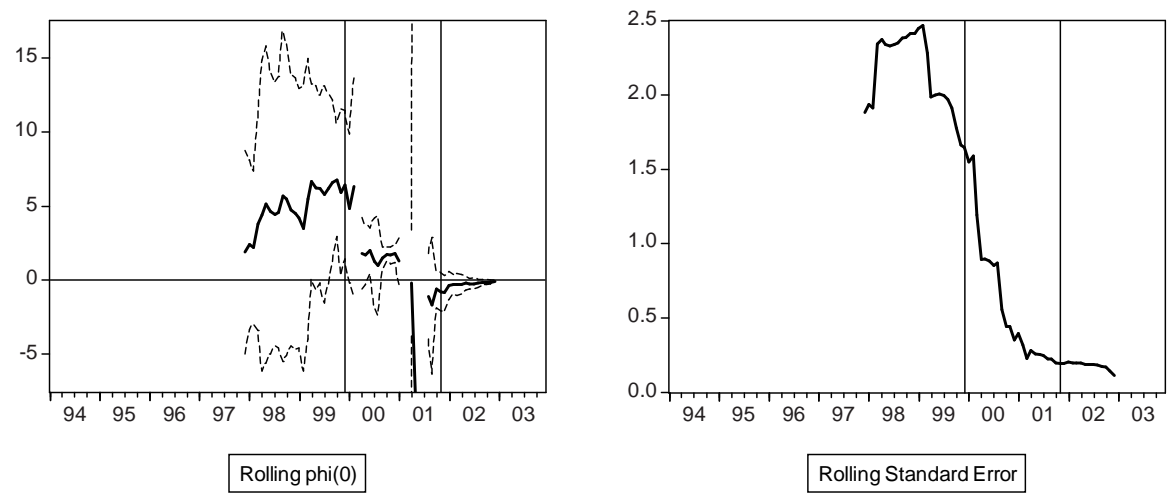

Notes: Panel (a) shows the spread between domestic and Euro area interest rate, the nominal exchange rate and UIP deviations, panel (b) $p$-values of backward recursive ADF and PP Unit root tests including a constant and automatic lag/bandwidth selection (AIC/Newey-West), backward recursive LR trace statistics (including a constant restricted to the cointegration space, lag length selection according to AIC) for the hypothesis of at most zero cointegration relations $(\operatorname{LR}(0)$, upper solid line is asymptotic 5\% critical value) and at most one cointegration relation ( $\mathrm{LR}(1)$, lower solid line is asymptotic $5 \%$ critical value), and (c) rolling estimates of $\phi_{0}$ (solid line ) \pm 2 standard errors (dashed lines) and rolling standard error of regression with a window size of 24 months. Time axis in (b) corresponds to sample beginning, the sample end is fixed at last available observation, the time axis in (c) indicates the end point of the respective window including the last 24 observations. Corresponding notes apply to figures 2-12. 

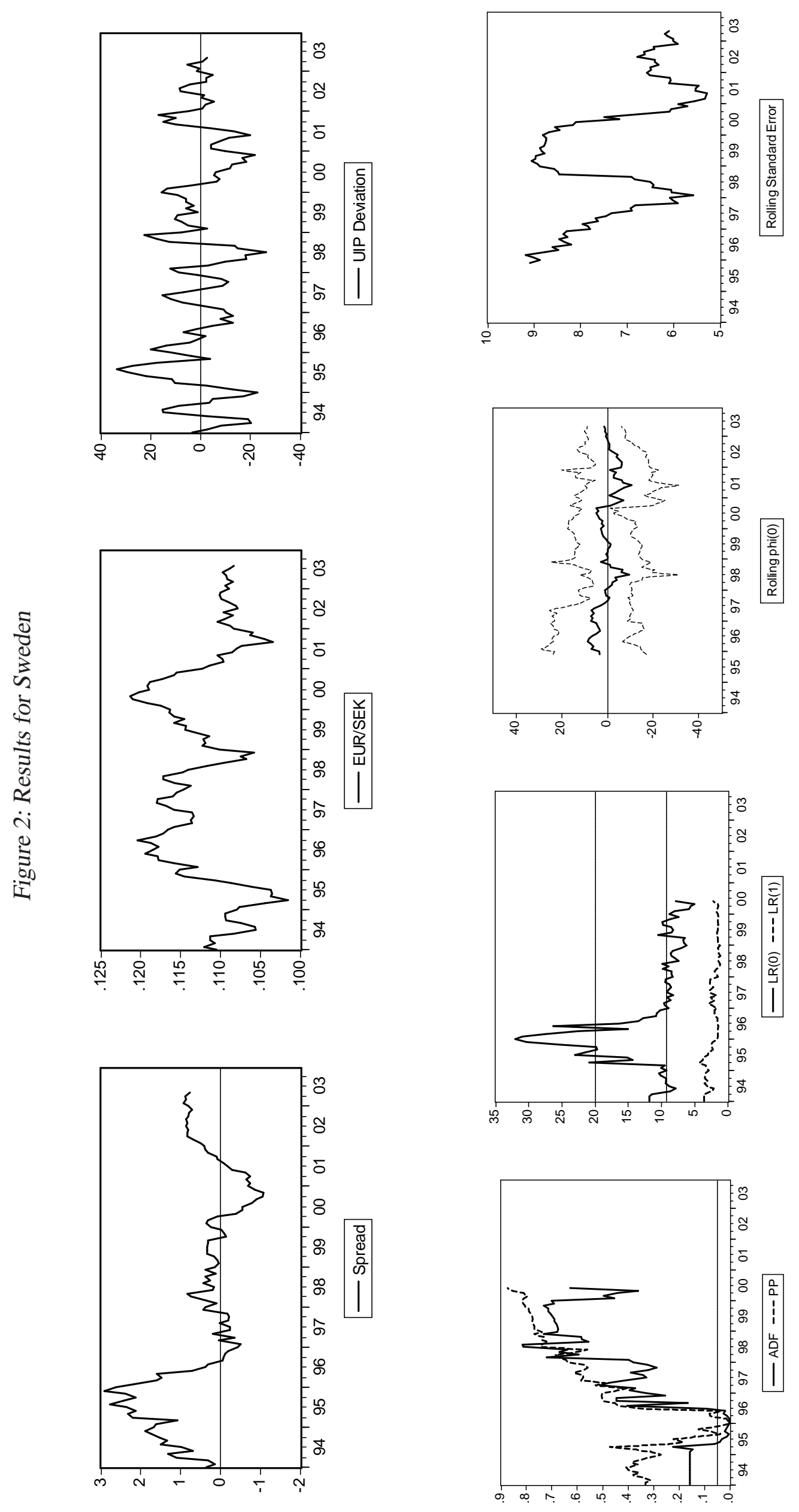

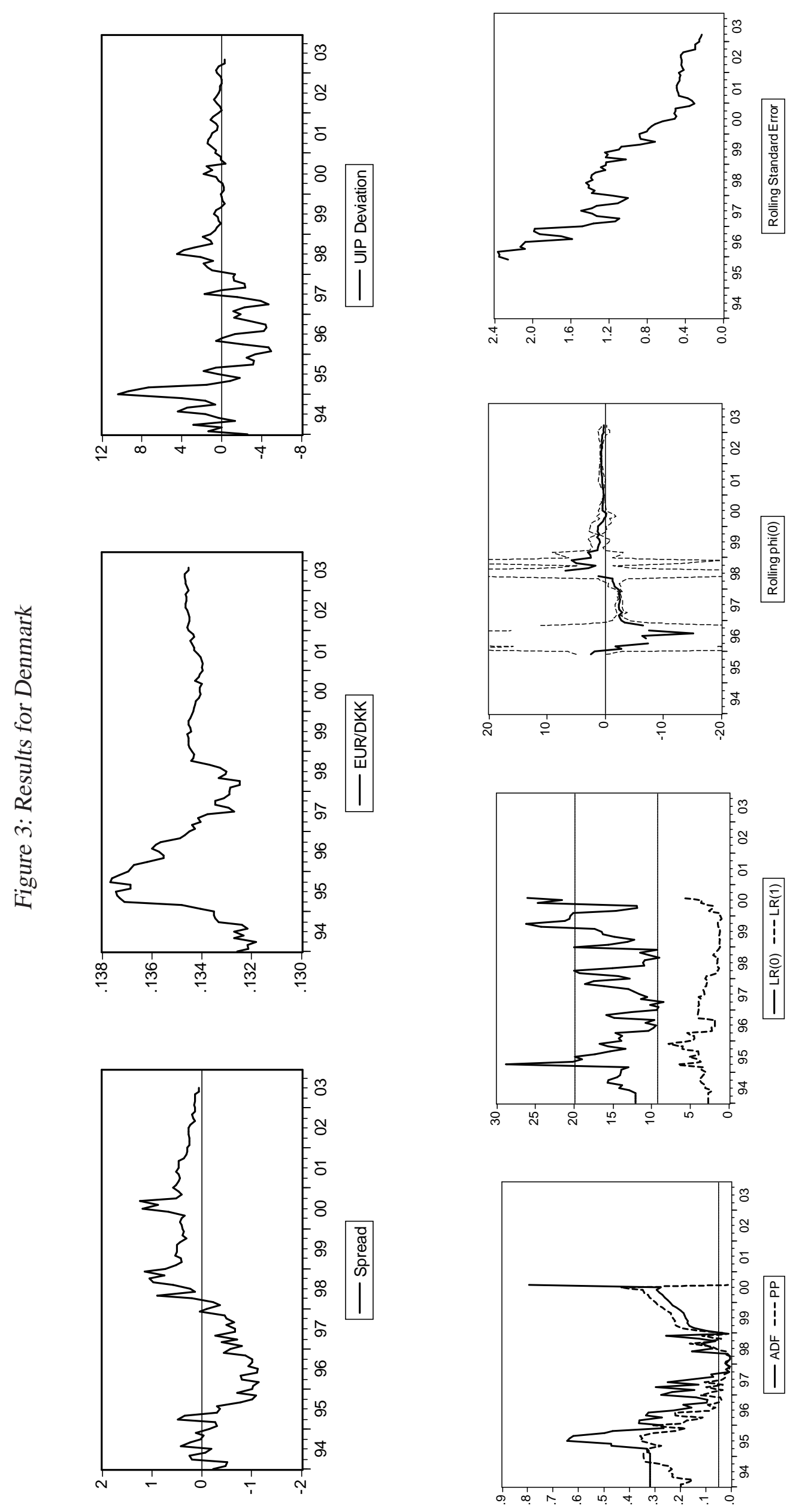

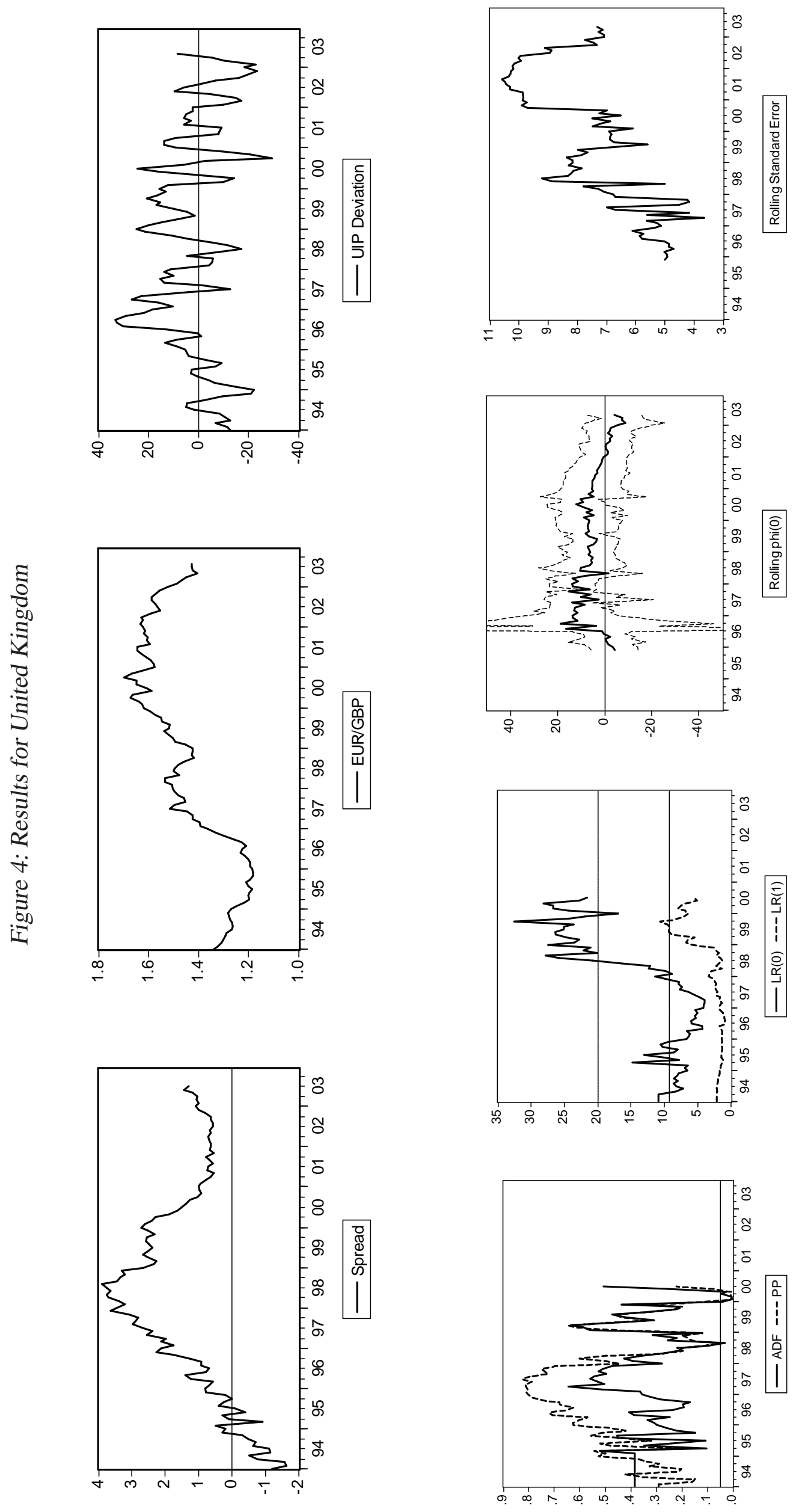



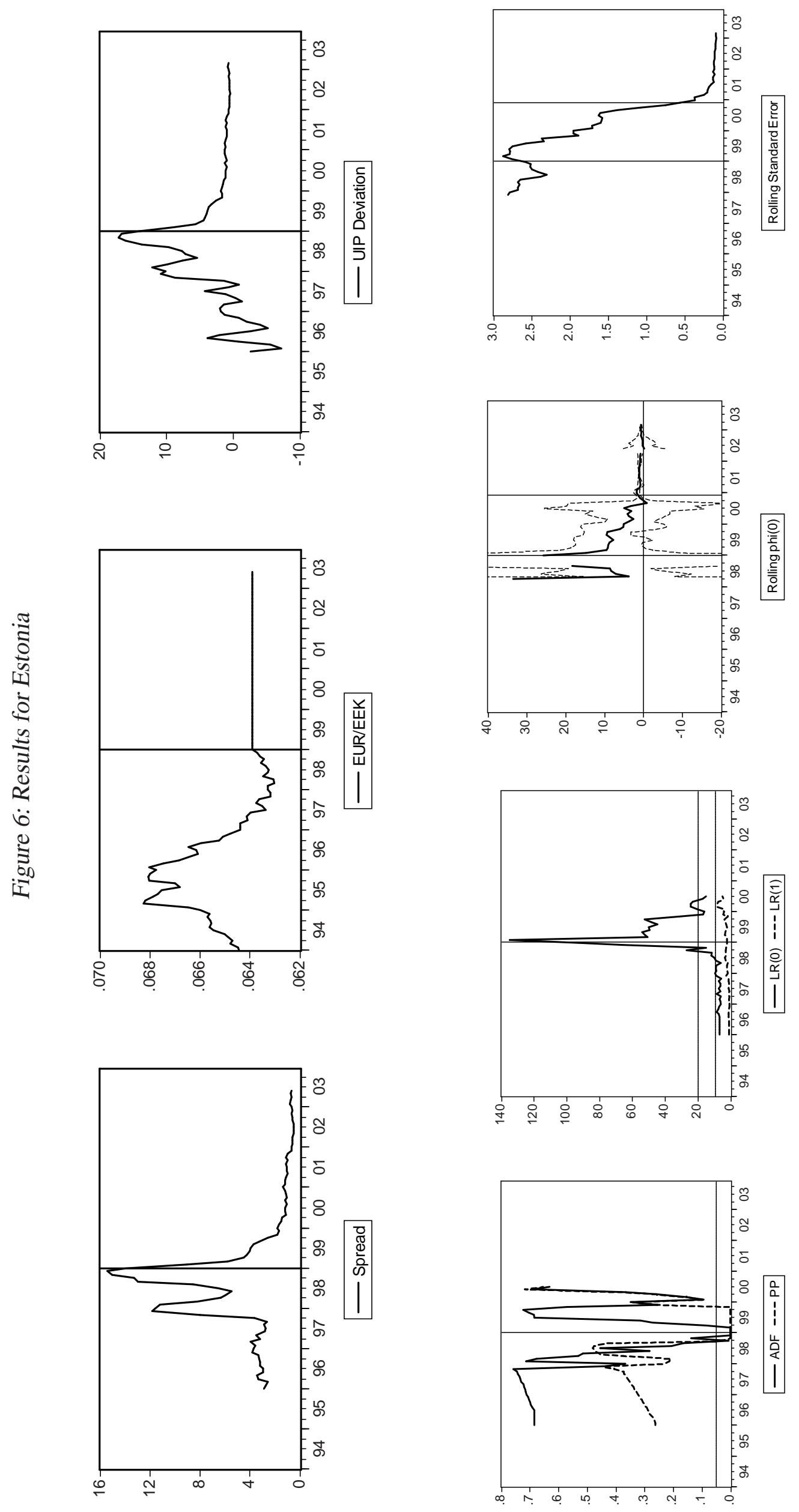

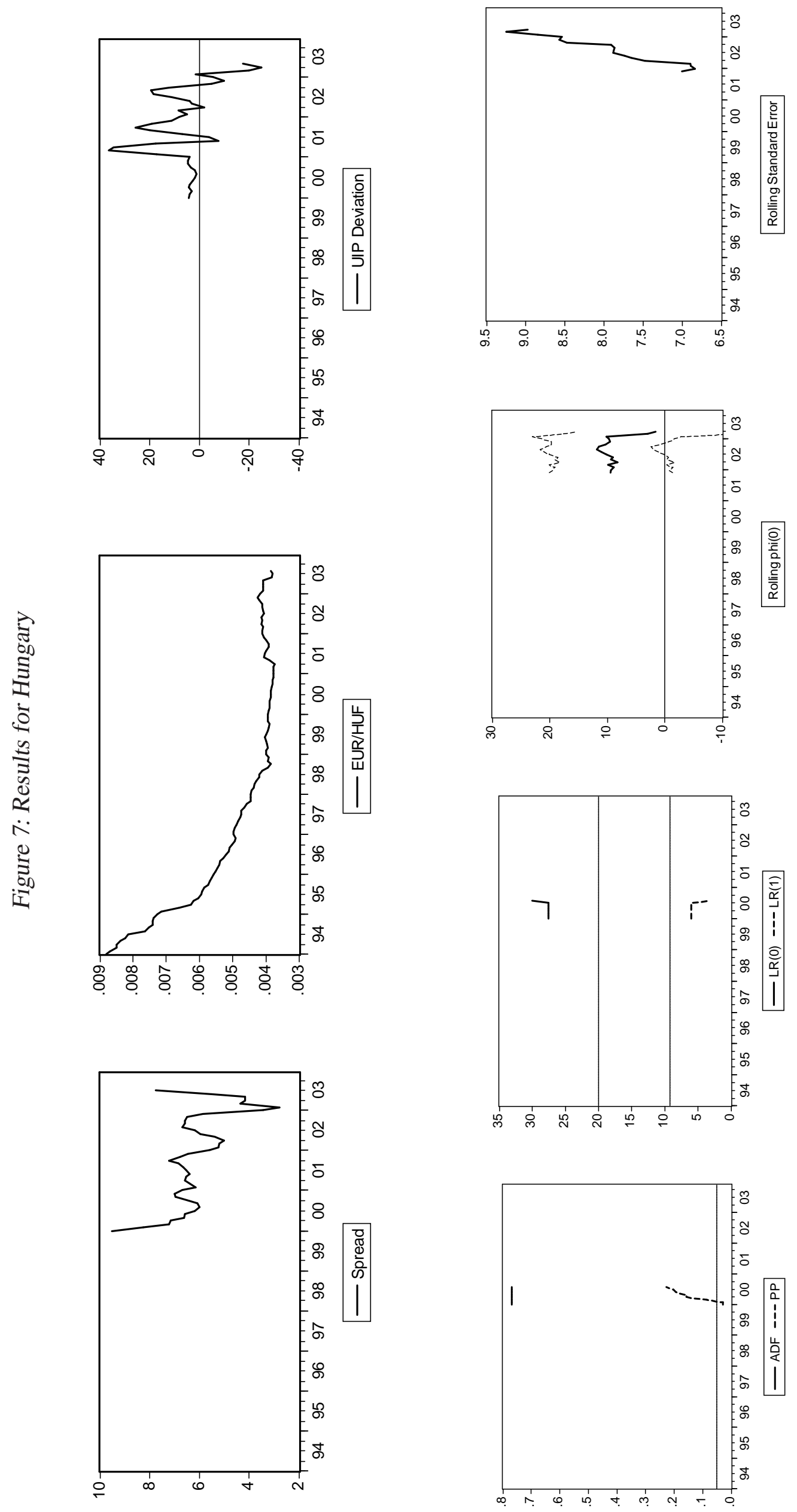

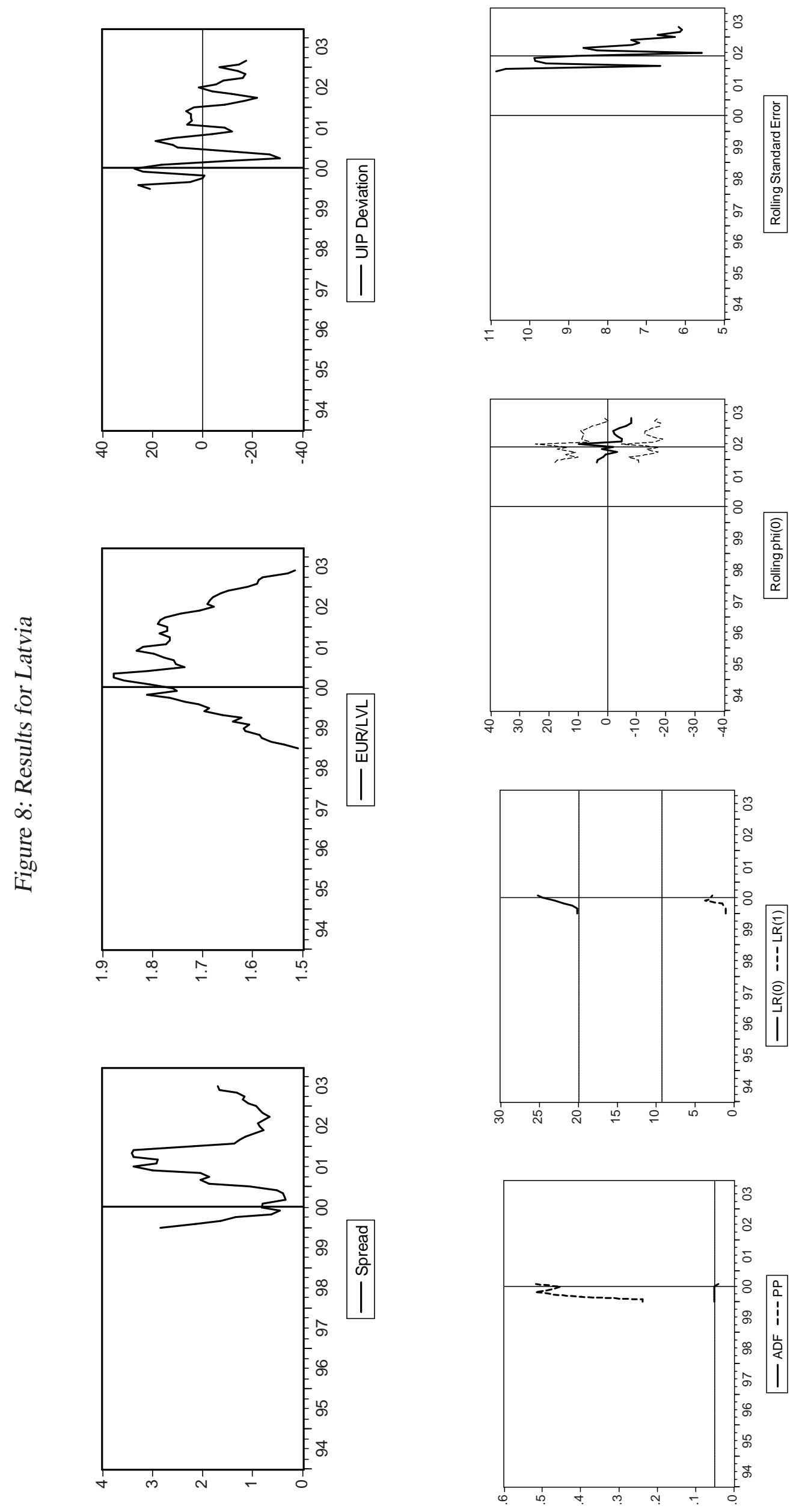

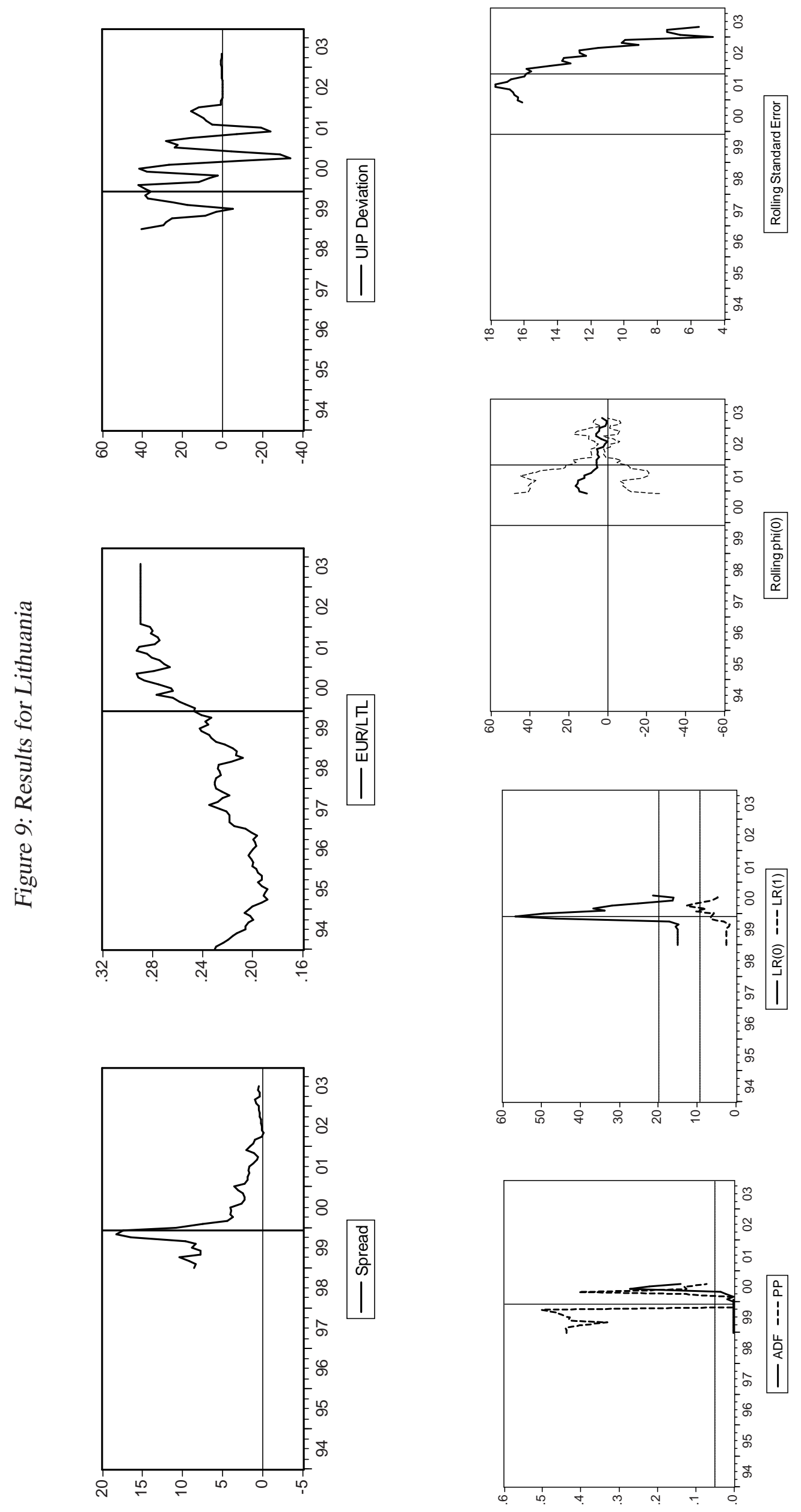

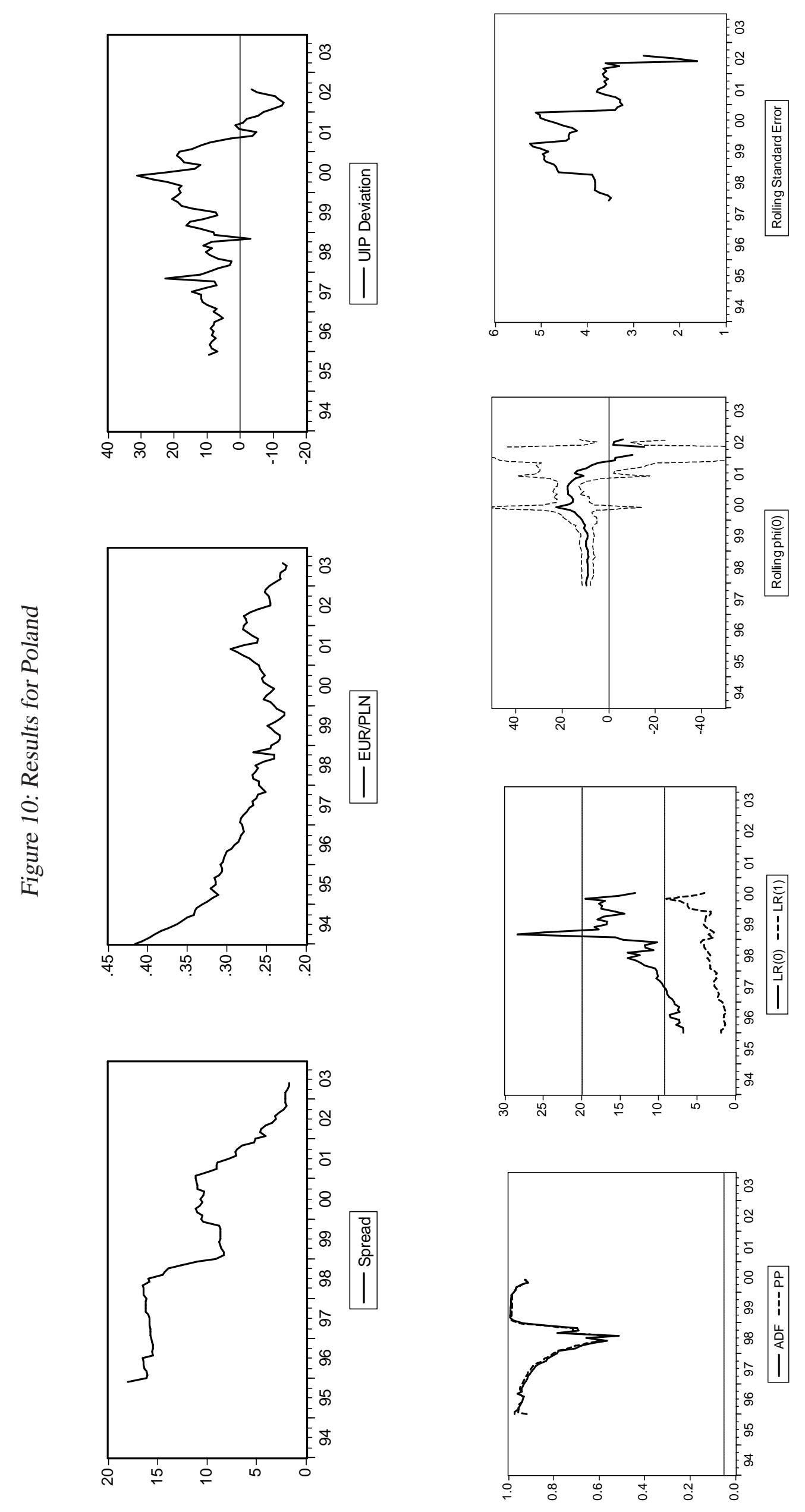

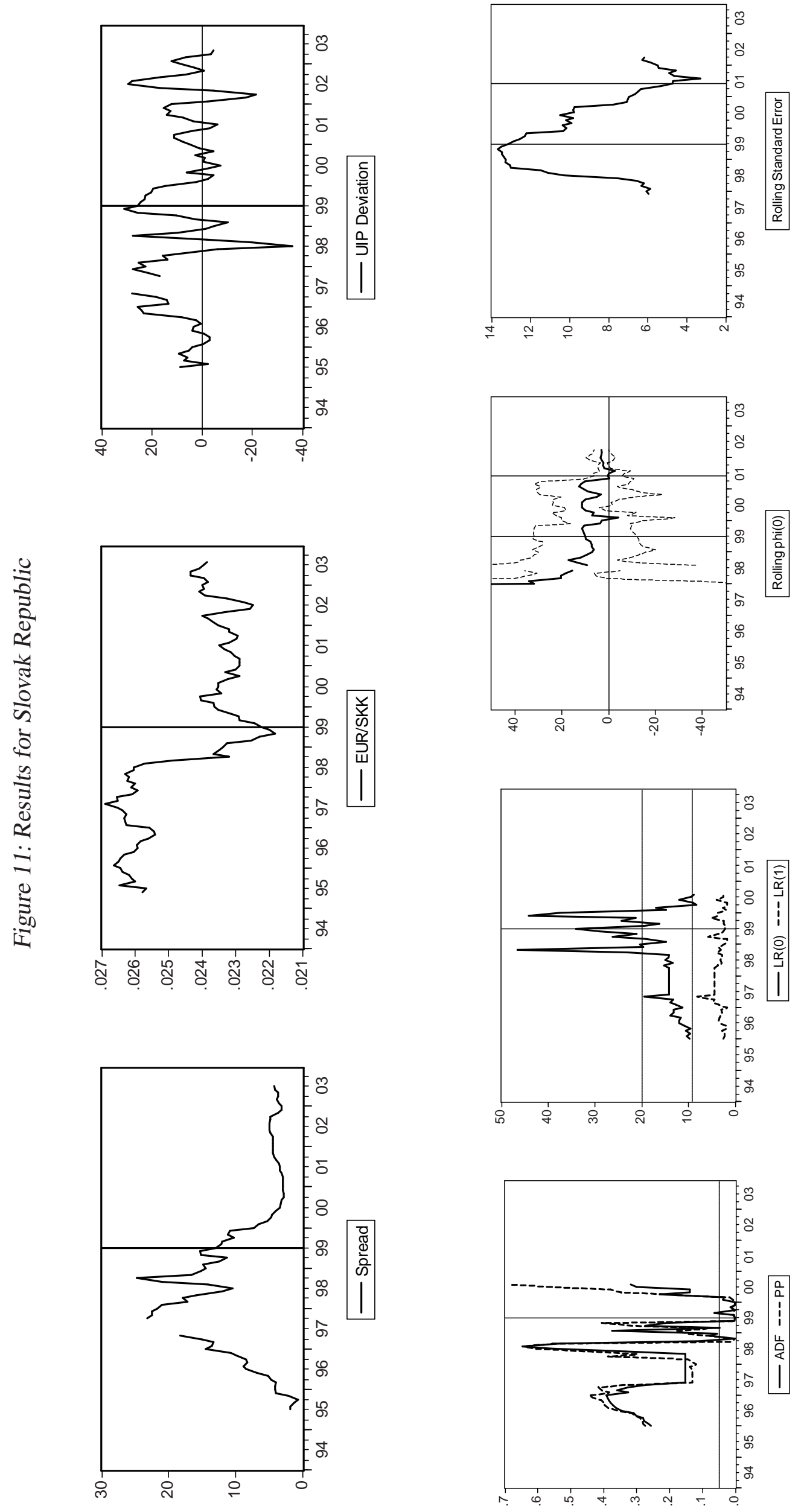

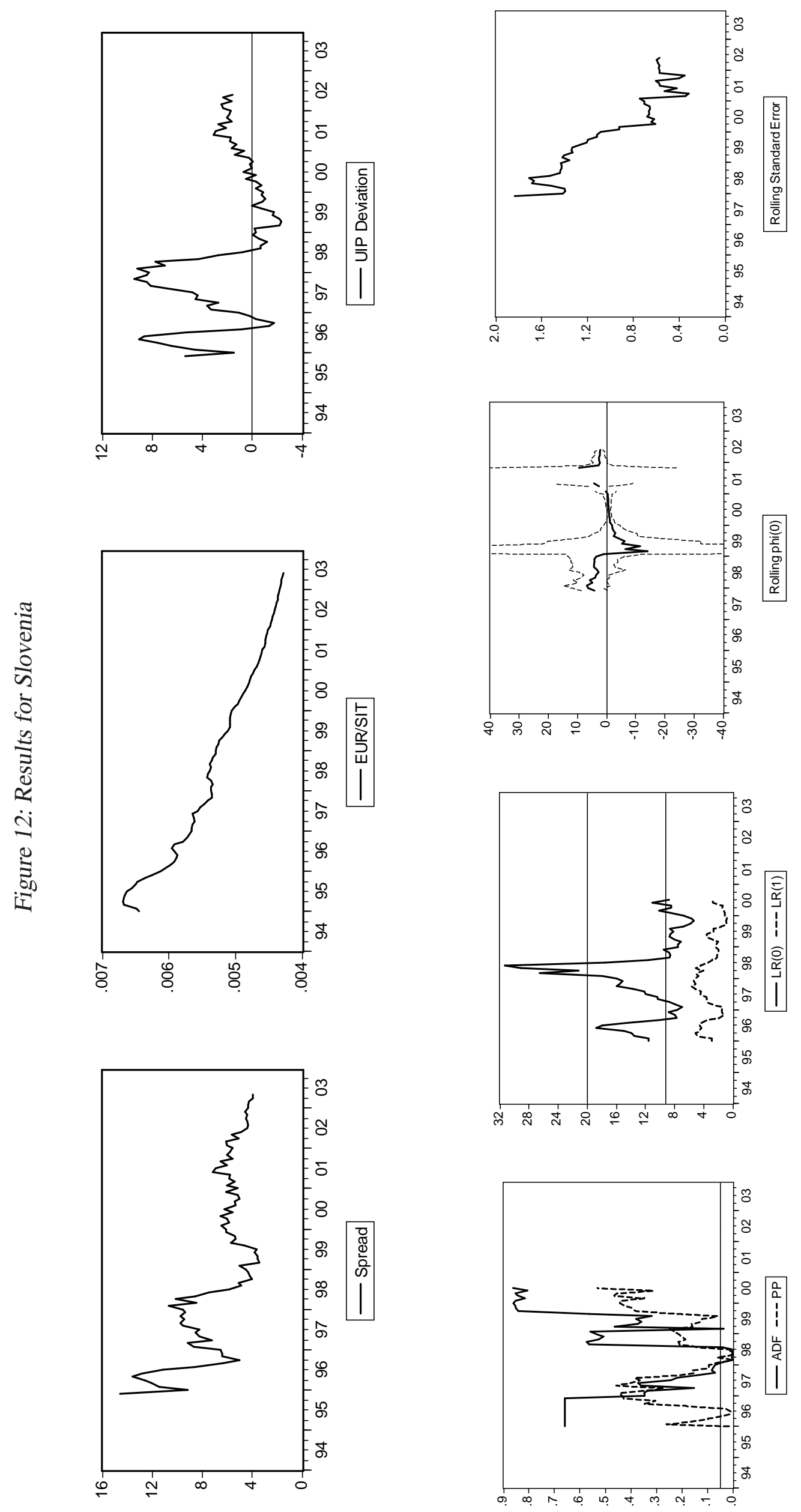

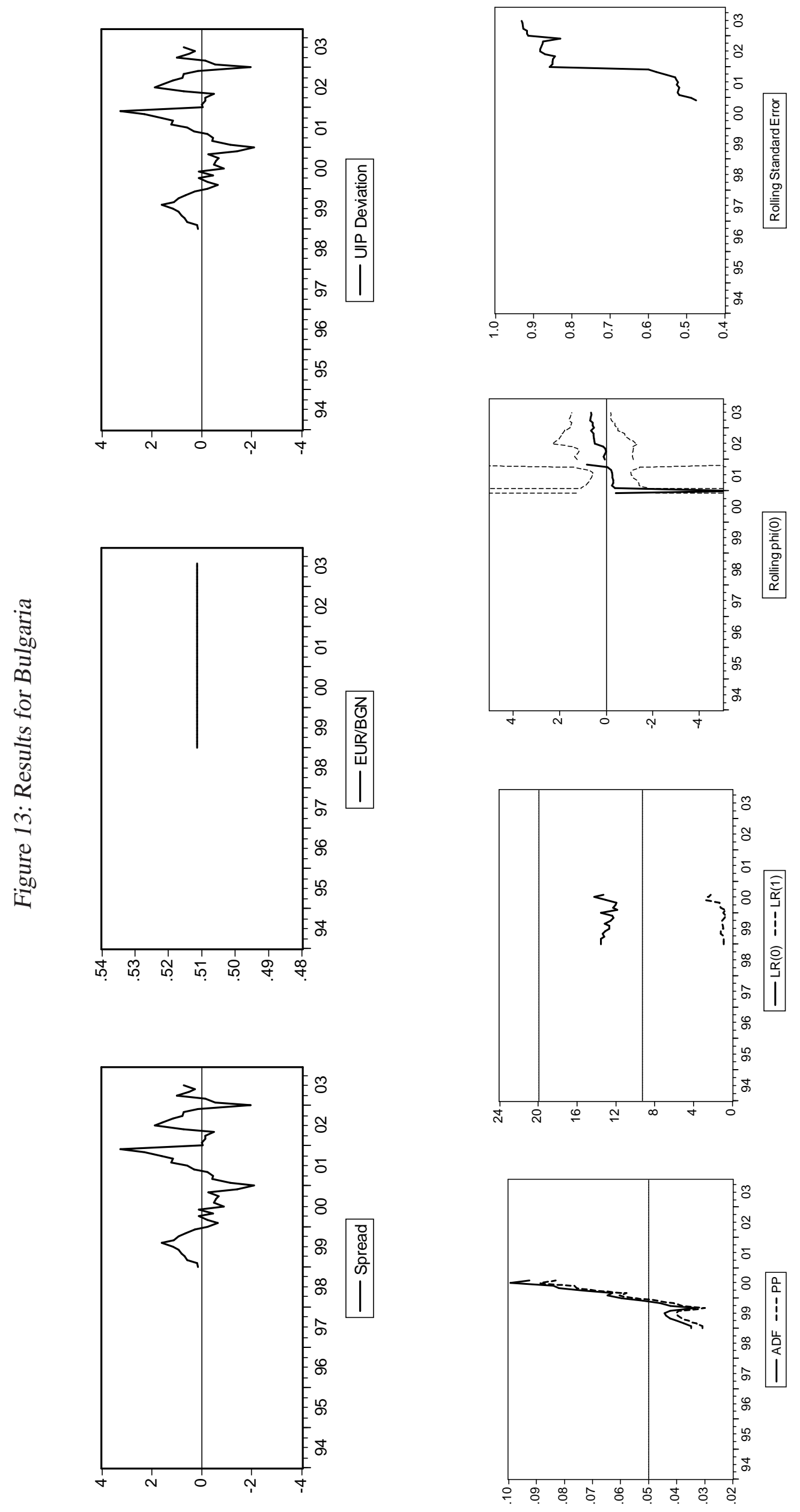

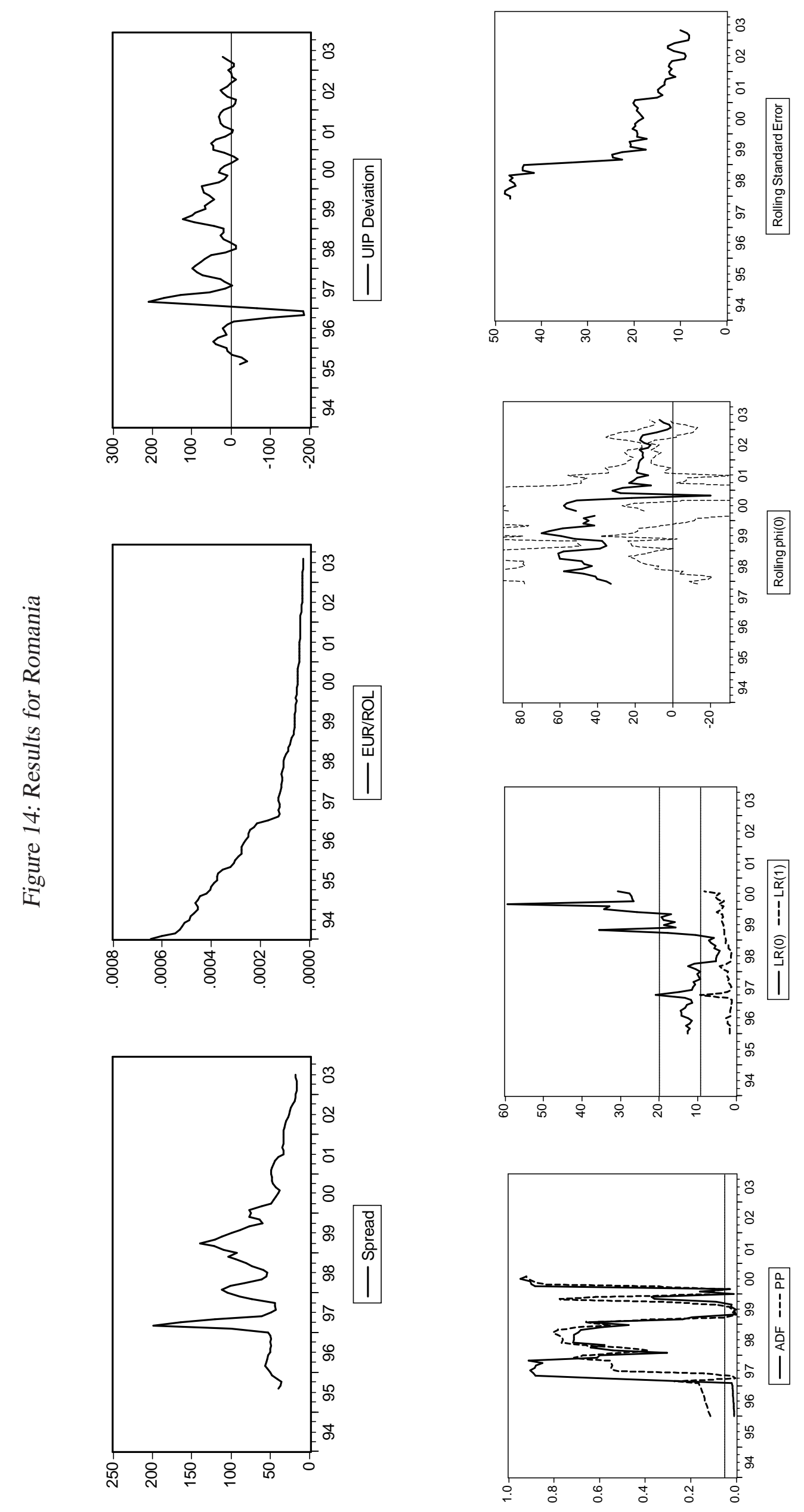


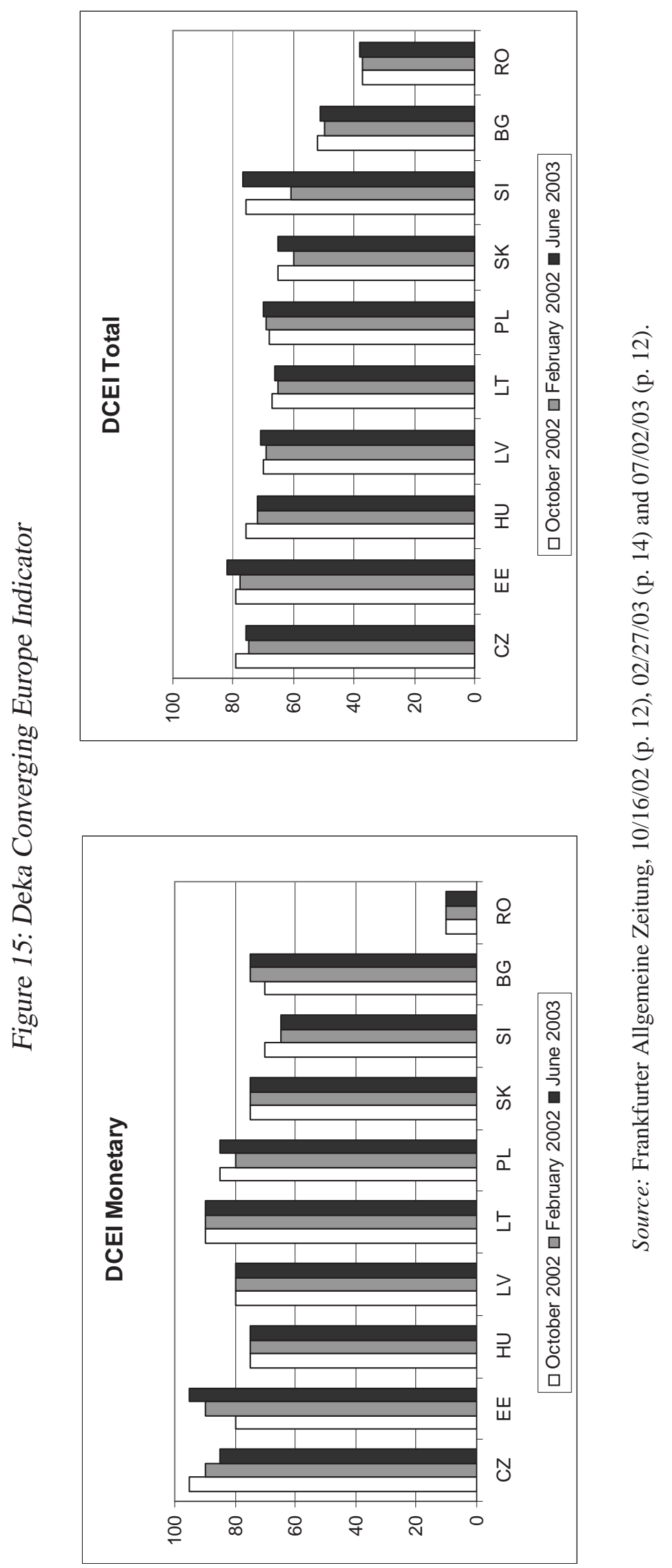




\section{References}

Batini, N./ Haldane, A. G. (1999): Forward-looking rules for monetary policy. In Taylor, J. B. (Ed.) Monetary policy rules, Chicago: The University of Chicago Press, 157-192.

Bayoumi, T./ Eichengreen, B. (1997): Ever closer to heaven? An optimum-currency-area index for European countries. European Economic Review, 41, 761-770.

Cheung, Y.-W./ Chinn, M. D./ Garcia Pascual, A. (2002): Empirical exchange rate models of the nineties: Are they fit to survive? Working Paper 9393, National Bureau of Economic Research.

Chinn, M. D./ Meredith, G. (1998): Long-horizon uncovered interest rate parity. Working Paper 6797, National Bureau of Economic Research.

DekaBank (2003): Deka Converging Europe Indicator. Unpublished document, available per email from economics@ dekabank.de.

Engel, C. (1996): The forward discount anomaly and the risk premium: A survey of recent evidence. Journal of Empirical Finance, 3, 123-192.

European Central Bank (2000): Convergence Report 2000.

European Central Bank (2001): The euro area after the entry of Greece. Monthly Bulletin, January, 35-41.

European Central Bank (2002a): Annual Report 2002.

European Central Bank (2002b): Convergence Report 2002.

de Grauwe, P. (2003a): Economics of monetary union. Fifth edition, Oxford: Oxford University Press.

de Grauwe, P. (2003b): The Euro at stake? The monetary union in an enlarged Europe. CESifo Economic Studies, 49, 103-121.

Hamilton, J. D. (1994): Time series analysis. Princeton: Princeton University Press.

Johansen, S. (1995): Likelihood-based inference in cointegrated vector autoregressive models. New York: Oxford University Press.

Johansen, S. (2000): A Bartlett correction factor for tests on the cointegration relations. Econometric Theory, 16, 740-778.

Johansen, S. (2002a): A small sample correction for tests of hypotheses on the cointegrating vectors. Journal of Econometrics, 111, 195-221.

Johansen, S. (2002b): A small sample correction for the test of cointegrating rank in the vectorautoregressive model. Econometrica, 70, 1929-1961.

Krugman, P. R./ Obstfeld, M. (2003): International economics. sixth edition , Boston: AddisonWesley.

Levich, R. M. (1989): Is the foreign exchange market efficient? Oxford Review of Economic Policy, 5, 40-60. 
Lothian, J. R. (2002): The internationalization of money and finance and the globalization of financial markets. Journal of International Money and Finance, 21, 699-724.

Lütkepohl, H. (2001): Vector autoregressions. In Baltagi, B. (Ed.) Companion to theoretical econometrics, chap. 32, Oxford: Blackwell, 678-699.

Mark, N. C. (2001): International Macroeconomics and Finance. Malden: Blackwell Publishers.

McCallum, B. T. (1994): A reconsideration of the uncovered interest rate parity relationship. Journal of Monetary Economics, 33, 105-132.

Merlevede, B./ Plasmans, J./ Aarle, B. v. (2003): A small macroeconomic model of the EUaccession countries. Open Economies Review, 14, 221-250.

Obstfeld, M./ Rogoff, K. (1995): Exchange rate dynamics Redux. Journal of Political Economy, 103, 624-660.

Orlowski, L. T. (2003): Monetary convergence and risk premiums in the EU accession countries. Open Economies Review, 14, 251-267.

Piazolo, D. (2000): Eastern Europe between transition and accession: an analysis of reform requirements. Kiel Working Paper 991, Kiel Institute of World Economics, Kiel.

Taylor, J. B. (1993): Macroeconomic policy in a world economy. New York: Norton \& Company.

Wolters, J. (2002): Uncovered interest rate parity and the expectations hypothesis of the term structure: empirical results for the US and Europe. In Klein, I./ Mittnik, S. (Eds.) Contributions to modern econometrics: from data analysis to economic policy, Festschrift in honor of Gerd Hansen, Kluwer, 271-282. 